\title{
Kepribadian Dalam Perspektif Sigmund Freud dan Al-Qur'an : Studi Komparatif
}

\section{Oleh: Muhammad Irfan Helmy}

\author{
Email: mihelmy@iainsalatiga.ac.id
}

IAIN Salatiga Indonesia

\begin{abstract}
Human personality depicts an individual's behavior and it is a formal object of psychology. Understanding human behavior is a vital and fundamental subject to understand human's essence. The typology of behavioral concept is multifaceted and varied. In fact, various definitions of personality arrive at a single substance. This paper analyses Sigmund Freud's concept on personality through the eye of Qur'an. The Qur'an made a personality concept as part of its focus. Through a comparative method, this study concludes that both Freud and the Qur'an argue that human personality consists of three components or potentials with different characteristics, yet integrated, to create human behavior and its personality. Freud calls them consecutively as Id, Ego and Superego; while the Quran calls them as Nafs, Akal and Kalbu. The difference between Freud and Quran on personality concept lies on the source where these three potentials came from. In Freud's view, they came from the human being themselves internally or being influenced by their surroundings. Freud did not count God's influence in his theory. According to Quran, however, the third potentials (Kalbu)depicts God's values embedded in human being. Kalbu is called as a God's disposition (tendency). Thus, Quranic concept on personality is theocentric while Freud's is anthropocentric which is much dependent on rationality and morality of human being.
\end{abstract}




\begin{abstract}
Abstrak
Kepribadian manusia merupakan gambaran tingkah laku seseorang yang menjadi objek formal kajian psikologi. Memahami prilaku manusia merupakan persoalan pokok yang bersifat radikal, vital dan menentukan pemahaman tentang hakikat manusia. Tipologi konsep kepribadian ternyata sangat beragam dan bervariasi. Pada intinya ragam definisi tentang kepribadian bermuara pada satu substansi. Artikel ini menganalisis konsep kepribadian Sigmund Freud dengan menggunakan kaca mata al-Qur'an. Ini karena al-Qur'an menjadikan kepribadian sebagai salah satu objek bahasannya. Dengan menerapkan metode komparatif, artikel ini sampai pada kesimpulan bahwa Keduanya sama-sama menyatakan bahwa kepribadian manusia mempunyai tiga daya dengan karakteristik berbeda yang ketiganya berintegrasi dalam mewujudkan tingkah laku dan kepribadian manusia. Jika menurut Freud tiga daya itu secara berurutan adalah Id, Ego, dan Superego, maka dalam konsep al-Quran ketiganya disebut dengan Nafsu, Akal dan Kalbu. Sedangkan perbedaan antara konsep Freud dan al-Qur'an tentang kepribadian terletak pada sumber dari tiga daya yang ada dalam diri manusia. Dalam pandangan Freud, ketiganya bersumber dari diri manusia sendiri atau pengaruh pihak luar atau lingkungan, sama sekali tidak ada campur tangan Tuhan di dalamnya. Sedangkan dalam konsepsi al-Qur'an, satu dari tiga daya itu, yaitu Kalbu adalah cerminan nilai-nilai ketuhanan dalam diri manusia. Karena itu, kalbu disebut dengan fitrah ilahiyah yang berarti celupan tuhan. Dengan demikian, kepribadian dalam alQur'an lebih bersifat teosentris, sedangkan dalam pandangan Freud lebih bersifat antroposentris yang hanya mengandalkan rasionalitas dan moralitas manusia.
\end{abstract}

Kata Kunci: Kepribadian; ego; superego; id; nafs. 


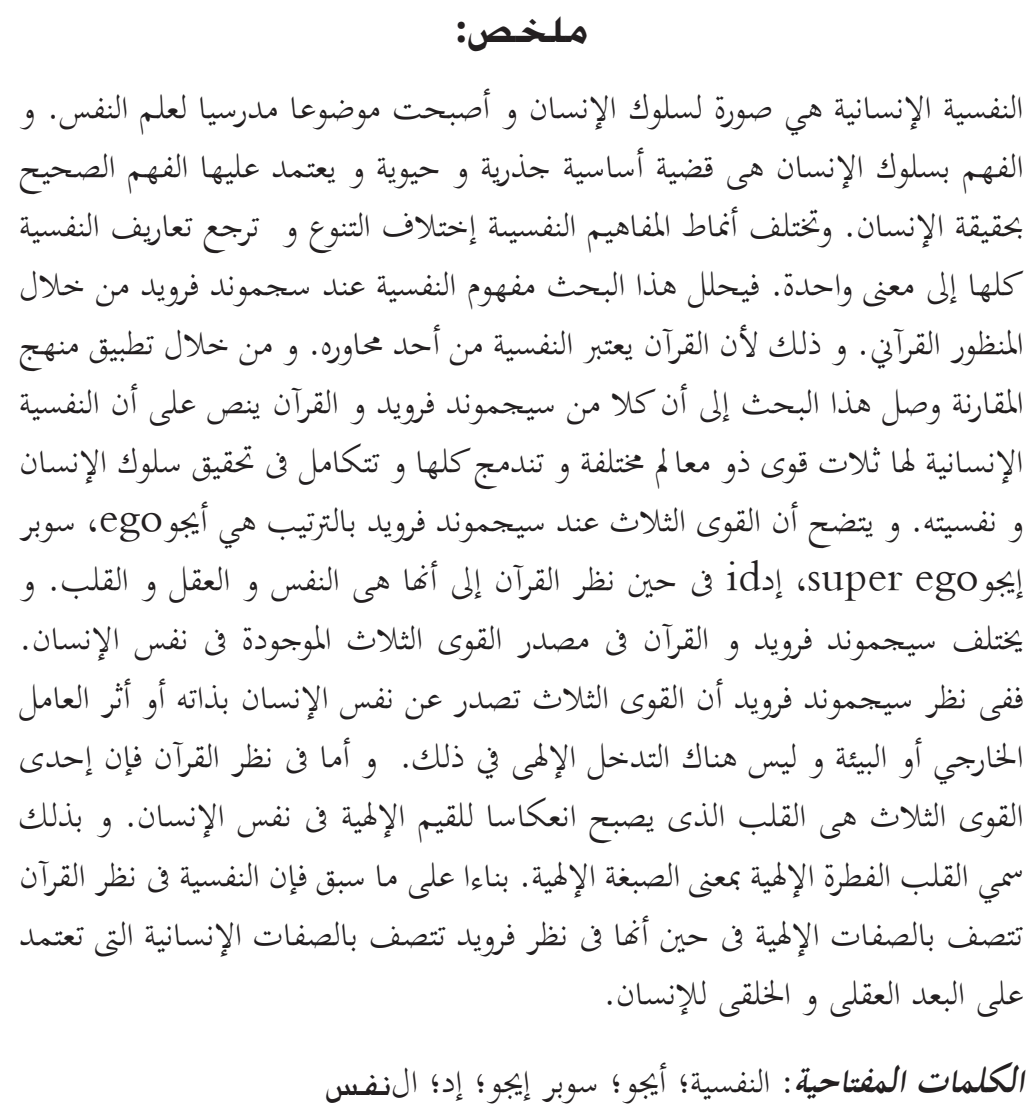

\section{A. Pendahuluan}

epribadian manusia merupakan gambaran tingkah laku
seseorang yang menjadi objek formal kajian psikologi.
Memahami prilaku manusia merupakan persoalan pokok yang bersifat radikal, vital dan menentukan pemahaman tentang hakikat manusia.

Kepribadian atau personality (Inggris), personalita (Perancis), persoonlijkheid (Belanda), personlicchkeit (Jerman), personalita (Italia), dan personalidad (Spanyol) merujuk pada akar kata yang merujuk pada akar kata yang berasal dari bahasa latin persona yang berarti topeng. 
Istilah ini pada awalnya berarti topeng yang dipakai oleh actor utama drama atau sandiwara. ${ }^{1}$

Tipologi konsep kepribadian ternyata sangat beragam dan bervariasi. Pada intinya ragam definisi tentang kepribadian bermuara pada satu substansi. Diantara pengertian itu adalah yang dikemukakan Sigmund Freud, yaitu yang didasarkan pada tiga titik kepribadian : ego, superego dan Id. Dalam kaitan ini, menarik menganalisis konsep kepribadian Sigmund Freud itu dengan menggunakan kaca mata alQur'an. Ini karena al-Qur'an menjadikan kepribadian sebagai salah satu objek bahasasannya.

\section{B. Kepribadian dalam Pandangan Sigmund Freud ${ }^{2}$}

1 Ikin Asikin, Konsep Kepribadian dalam Perspektif Psikologi Barat Kontemporer dan Islam, dalam Jurnal Ta’dib, Vol. 3 No.2, Agustus 2003, hlm. 253.

2 Freud lahir di Freibergh Moravia pada tanggal 6 Mei1856, bagian dari Eropa Tengah yang kemudian berada di bawah kekuasaan kerajaan Austro-Hongaria. Keluarganya adalah penganut agama yahudi. Ayahnya bekerja sebagai seorang pedagang dan menikah untuk kedua kalinya saat dua orang putranya yang lain sudah tumbuh dewasa. Freud sendiri adalah anak pertama dari istri kedua ayahnya. Freud dibesarkan dalam sebuah keluarga besar.

Saat masih berusia empat tahun, Freud dan keluarganya pindah ke ibukota kerajaan Vienna. Di sinilah Freud kemudian menetap dan bekerja hampir sepanjang usianya. Dia hanya keluar dari kota ini setahun menjelang kematiannya, yaitu ketika serangan pasukan Nazi ke Austria pada tahun 1938 yang memaksanya mengungsi ke Inggris.

Di Vienna, Freud tidak mempunyai kebebasan untuk menunjukkan keyahudiannya di tengah komunitas yang didominasi oleh penganut Kristen Katolik, meskipun keluarganya tetap tinggal di kota ini. Karena itu, orang tua Freud, meski mendidik anak-anaknya dengan ajaran-ajaran Yahudi, dalam kesehariannya mereka tetap mengikuti aturan dan kebiasaan yang berlaku di dalam masyarakat setempat. Mereka tidak mengikuti aturan makan Yahudi dan menyesuaikan diri dengan hari-hari besar Kristen, seperti Natal dan Paskah.

Pada pendidikan menengahnya, Freud adalah siswa yang berbakat. Ia belajar bahasa Yunani, Latin dan Ibrani. Dia berhasil menyelesaikan studiya dengan rangking tertinggi di kelasnya. Selain bahasa Jerman sebagai bahasa ibunya, Freud juga menguasai bahasa Perancis, Inggris, Spanyol dan Italia. Pada tahun 1873, saat berusia 17 tahun, Freud menjadi mahasiswa kedokteran di Universitas Vienna dan menamatkannya pada tahun 1881.

Tamat dari Fakultas kedokteran, Freud bekerja sebagai dokter di rumah sakit umum Vienna. Di sini Freud terus melanjutkan penelitiannya tetang otak manusia. Beberapa tahun lamanya Freud juga melakukan penelitian tentang kokaine, sejenis obat bius (1884-1887). 


\section{Pandangan Sigmund Freud tentang kepribadian seseungguhnya} dapat dilacak dari teorinya tentang mimpi. Dalam penelitiannya tentang mimpi, Freud sampai pada kesimpulan bahwa seluruh aktivitas manusia -baik yang normal maupun yang tidak normalsangat dipengaruhi oleh alam bawah sadar. Mimpi pada taraf tertentu mengindikasikan seluruh manusia mengidap neurotis. Yang terpenting dalam hal ini adalah bahwa interpretasi terhadap mimpi yang berasal dari alam bawah sadar sama persis dengan yang dijalani oleh orang yang mengalami ketertekanan dan menjelma menjadi perilaku aneh dan kebiasan neurotis lainnya. Jadi, bagi para psikoanalis, interpretasi terhadap sebuah mimpi akan menghasilkan kesimpilan yang sama ketika menafsirkan perilaku seseorang yang mengalami neurotis, yaitu keduanya sama-sama membentangkan jalan menuju gerbang misteri alam bawah sadar. ${ }^{3}$

Pada tahun 1886 ia menikah dengan Martha Bernays dan karena alasan ekonomis ia mengurangi riset ilmiah dan membuka praktek sebagai dokter syaraf. Namun ia meneruskan penelitian di bidang neurology dan setelah berkunjung ke Berlin ia menulis beberapa karangan penting tentang cacat otak pada anak-anak. Lama kelamaan perhatiannya bergeser dari neurology ke psikopatologi. Terpengaruh oleh Josef Breuer, sekitar tahun 1888 ia mulai memanfaatkan hipnosa dan sugesti dalam praktek medisnya. Freud juga menulis buku bersama Breuer yang merupakan karya pertamanya yang berjudul Studies on Hysteria (1895). Buku ini sangat penting artinya bagi buku-buku Freud selanjutnya

Pada tahun 1990, Freud menulis buku The Interpretation of Dreams. Buku ini adalah catatan tentang apa yang dating dalam mimpinya dan mimpi pasiennya. Buku ini telah membuka zaman baru, sebab diterbitkan di awal abad baru yang menghantarkan revolusi Freudian ke dalam pemikiran modern. Buku ini adalah kerangka bagi salah satu konsep penting Freud, yaitu alam bawah sadar.

Pada tahun berikutnya, karya-karya baru tentang Psikoanalisa mengalir tanpa henti dari pena Freud. Freud menulis karya-karyanya seperti The psychophatology of Everyday Life (1901), Three Essays on The Theory of Sexsuality (1905), Totem and Taboo (1913), Introductory Lectures on Psychoanalysis (1916-1917), Beyond the Pleasure Principal (1920), The Ego and Id (1923), dan The Question of Lay Analysis (1926).

Dua dekade menjelang tutup usia, freud masuh menghasilkan karya-karyanya yang kontroversial dengan penekanan bidang psikoanalisa tentang masalah-masalah umum, seperti kemasyarakatan, ilmu pengetahuan dan agama. Hal itu tercakup dalam buku The Future of an Illusion (1927) dan Moses and Monotheism (1938). Sigmund Freud meninggal di London pada tahun 1939.

3 Daniel L. Pals, Dekonstruksi Kebenaran : Kritik Tujuh Teori Agama, terj. Inyiak Ridwan Munzir dan M. Syukri, (Yogyakarta: Ircisod, 2003), hlm. 89. 
Karena mimpi adalah suatu produk psikis dan karena hidup psikis dianggap sebagai konflik antara daya-daya psikis, maka Freud memahami mimpi sebagai perwujudan suatu konflik. Dalam kerangka ini, perlu dilihat bahwa keberadaan dorongan-dorongan jasmaniah yang menimbulkan konflik dalam kepribadian, bagi Freud adalah hal yang lumrah. Ia mempresentasikan rasa ingin puas dan senang. Ketegangan dan tekanan yang kemudian muncul juga berbeda-beda. Mereka bisa terlibat dalam konflik ketika bertabrakan satu sama lain atau ketika berhadapan dengan kenyataan dari dunia luar yang tidak bisa diubah. ${ }^{4}$

Dari sini, muncullah ide tentang konflik antara kelompok dorongan itu sendiri dan antara dorongan dengan dunia luar. Ide ini kemudian menggiring Freud kepada konsep yang paling terkenal di antara konsepnya yang lain, yaitu tiga titik kepribadian manusia sebagai Ego (kata latin untuk "aku”), Superego (kata latin untuk "aku yang tinggi/di atas") dan $\boldsymbol{I} \boldsymbol{d}$ (kata latin untuk “ini/itu”) ${ }^{5}$

Dalam skema ini, Id dianggap sebagai yang pertama dan paling dasar diantara ketiga elemen tadi. Dia berakar dari tahap paling awal, yaitu fase hewaniyah dari evolusi manusia. Dia merupakan alam bawah sadar yang tidak menyadari dirinya sendiri. Di sinilah letak dasar semua dorongan fisik yang berubah menjadi bentuk ekspresi mental dalam tindakan. ${ }^{6}$

Di titik yang berlawanan, yang dapat dikatakan sebagai bagian teratas kepribadian terdapat superego. Dia mempresentasikan pengaruh-pengaruh yang sejak lahir telah mulai dimasukkan ke dalam kepribadian seseorang oleh dunia luar (masyarakat, keluarga, suku, kota, Negara dan lain-lain). ${ }^{7}$

\footnotetext{
$4 \quad$ Ibid., hlm. 90

5 Ibid., hlm. 91

6 Ibid.

7 Ibid., hlm. 92
} 
Sedangkan yang terletak ditengah-tengah antara Id dan superego adalah Ego atau prinsip realitas. Ego dapat dikatakan sebagai pusat penentu pilihan kepribadian manusia. Tugas utamanya adalah menampilkan keseimbangan yang kontinu dalam diri manusia. Di satu pihak ia harus memenuhi keinginan Id, namun di pihak lain dia harus siap menyokong atau menolak keinginan tersebut ketika bertabrakan dengan kenyataan yang sulit dari alam fisik atau berhadapan dengan larangan sosial yang diperintahkan oleh superego. ${ }^{8}$ Dalam kaitan ini, seperti yang dikutip Daniel L. Pals, Freud menulis,"Berperilaku dengan ego akan berhasil dengan baik jika selalu bisa memenuhi tuntutan Id, superego dan realitas, atau dengan kata lain, dia bisa mendamaikan tuntutan masing-masing."

Sungguhpun demikian, pembagian ketiga elemen ini menyisakan satu perdebatan. Ketika Freud mendefinisikan Ego sebagai sebagai sesuatu yang terpisah dari Id dan superego, maka pertanyaan yang muncul adalah, apakah ego itu sama dengan keseluruhan pribadi-yang berarti akan memasukkan Id dan superego di dalam dirinya- atau apakah ego itu merupakan pelaku yang berusaha membedakan dirinya dari Id dan superego? ${ }^{10}$

Pilihan terhadap yang pertama akan membuka kemungkinan tentang suatu ego yang pada akhirnya identik dengan dirinya. Sedangkan pilihan terhadap yang kedua akan membuat adanya kemungkinan tentang identitas diri menjadi problematik. ${ }^{11}$

\section{Kepribadian dalam Pandangan al-Qur'an}

Istilah kepribadian (personality) secara etimologi dalam studi keislaman lebih dikenal dengan term syakhashiyah yang berasal

\footnotetext{
$8 \quad$ Ibid., hlm. 92

9 Ibid.

10 John Lechte, Lima Puluh Filsuf Kontemporer dari Strukturalisme sampai Post Modernisme, terj. Gunawan Admiranto, (Yogyakarta: Kanisius, 2001), hlm. 49. 11 Ibid.
} 
dari kata syakhsh yang berarti pribadi. Term berikutnya adalah nafsiyah yang berasal dari kata nafs yang berarti pribadi. Al-Shafi'i menerjemahkan kata nafs dengan personality, self, or level of personality development yang artinya kepribadian, diri, pribadi atau tingkat suatu perkembangan kepribadian. ${ }^{12}$

Term nafsiyah lebih banyak dipakai dalam leksikologi al-Qur'an dan hadits. Pada sisi lain, al-Quran sama sekali tidak menyebutkan term syakhshiyah untuk menunjukkan makna kepribadian. Dengan demikian, term nafsiyah lebih tepat dijadikan sebagai padanan bagi term personality. Hanya saja, term nafs memilki multi makna. Nafs dapat berarti nyawa, daya konasi yang memiliki sifat ghadhab (defense) dan syahwat (appetite), dan struktur gabungan antara jasmani dan ruhani, atau juga keperibadian. Multimakna inilah yang menjadikan term nafs lebih sedikit dipergunakan dalam diskursus psikologi Islam.

Ditinjau dari sisi terminologis, kepribadian mempunyai banyak pengertian. Definisi yang mencerminkan makna kepribadian Islami sesungguhnya adalah definisi yang berpijak pada struktur fitrah yaitu intergrasi system kalbu, akal dan nafsu manusia yang menimbulkan tingkah laku. Definisi ini sederhana, namun memiliki konsep yang mendalam dan sekaligus sebagai bandinga bagi definisi yang dikemukakan oleh Sigmund Freud.

Manusia memiliki fitrah jasmani sebagai struktur biologis kepribadiannya dan fitrah ruhani sebagai struktur psikologis kepribadiannya. Gabungan fitrah ini disebut dengan fitrah nafsani yang merupakan struktur psikopisik kepribadian manusia. Fitrah nafsani memiliki tiga daya: (1) Kalbu (fitrah Ilahiyah) sebagai aspek supra kesadaran manusia yang berfungsi sebagai daya emosi (rasa). (2) Akal (fitrah Insaniyah) sebagai aspek kesadaran manusia yang berfungsi sebagai daya kognisi (cipta). (3) Nafsu (Fitrah Hayawaniyah) sebagai

12 Subandi, Psikologi dan Sufisme, dalam Membangun Paradigma Psikologi Islami (Ed.), Fuad Nashori, (Yogyakarta: Sipress, 1994), hlm. 94. 
aspek pra atau bawah kesadaran manusia yang berfungsi sebagai daya konasi (karsa). ${ }^{13}$

Ketiga komponen fitrah nafsani ini berintegrasi untuk mewujudkan suatu tingkah laku. Sedangkan dari sudut tingkatannya, maka kepribadian itu merupakan integrasi dari aspek-aspek supra kesadaran (fitrah ketuhanan), kesadaran (fitrah kemanusiaan) dan pra atau bawah kesadaran (fitrah kebinatangan). Sedangkan dari sudut fungsinya, kepribadian merupakan integrasi dari daya-daya emosi, kognisi dan konasi, yag terwujud dalam tingkah laku luar seperti berjalan, berbicara maupun tingkah laku dalam seperti pikiran dan perasaan.

Manusia dalam pandangan konsep kepribadian Islam, telah memiliki seperangkat potensi, disposisi dan karakter unik. Potensi itu paling tidak mencakup keimanan, ketauhidan, keselamatan keikhlasan, kesucian, kecenderungan menerima kebenaran dan kebaikan, dan sifat baik lainnya. Semua potensi itu bukan diturunkan dari orang tua, melainkan diberikan oleh Allah SWT sejak di alam perjanjian (mitsaq). ${ }^{14}$ Ini berbeda dengan aliran Nativisme yang mengatakan bahwa factor pembentuk kepribadian adalah sifat-sifat dan karakteristik yang diturunkan orang tua kepada anaknya. Berbeda pula dengan aliran Empirisme yang mengatakan bahwa faktor pemebentuk kepribadian adalah lingkungan (environment). ${ }^{15}$.

Dalam Islam, proses pemberian potensi-potensi yang membentuk kepribadian, terjadi melalui struktur fitrah ruhani. Karena itu, fitrah ruhani disebut juga fitrah al-munazzalah. Ketika struktur fitrah ruhani menyatu dengan fisik yang ditandai dengan kehidupan janin di dalam rahim sang ibu, maka ia berubah wujud menjadi fitrah nafsani. Jadi tugas perkembangan fitrah nafsani adalah mengaktualisasikan semua

13 Abdul Mujib dan Yusuf Muzakir, Nuansa-Nuansa Psikologi Islam, (Jakarta: Raja Grafindo Persada, 2001), hlm. 133.

14 QS. Al-Arraf: 172

15 Abdul Mujib dan Yusuf Muzakir, Nuansa-Nuansa Psikologi Islam, hlm. 168 
potensi yang sesuai dengan potensi-potensi ruhaniah yang berasal dari Allah, bukan dari warisan orang tua.

Fitrah nafsani mengikuti adanya factor bawaan atau warisan, namun factor itu masih bersifat potensial dan bukan actual. Aktualisasi potensi itu bukan tergantung pada penyerahan takdir belaka melainkan tergantung pada usaha manusia sendiri. Tanpa adanya usaha manusia, semua potensi bawaan itu tidak akan terwujud dengan baik.

Berdasarkan serangkaian fungsionalisasi aspek pisik maupun aspek psikis dalam pembentukan kepribadian, berikut ini ada tiga komponen nafsani yang disebut al-Qur'an yang memiliki saham dalam pembentukan kepribadian ${ }^{16}$ yaitu:

\section{Kepribadian Ammarah (al-nafs al-ammarah)}

Kepribadian ammarah adalah kepribadian yang cenderung pada tabiat jasad dan mengejar pada prinsip-prinsip kenikmatan (pleasure principle). Ia menarik kalbu manusia untuk melakukan perbuatanperbuatan yang rendah sesuai dengan naluri primitifnya, sehingga ia merupakan tempat dan sumber kejelekan dan tingkah laku yang tercela.

Ketinggian dan kerendahan kualitas nafs diukur dengan tingkat hubungannya dengan Tuhan. Nafs kualitas tinggi adalah nafs yang sudah sampai pada tingkat dipanggil Tuhan untuk kembali kepada-Nya dengan senang dan diridhai, atau sekurang-kurangnya menyesali diri karena kurang menggunakan peluang. Sedangkan nafs kualitas rendah, dalam pandangan al-Qur'an ada empat karakter yang menandainya: (a) secara mudah melanggar apa yang dilarang Allah (b) menuruti dorongan hawa nafsu (c) menjalankan maksiat dan, (d) tidak mau memenuhi panggilan kebenaran. ${ }^{17}$ Secara eksplisit al-Qur'an menyebutnya dengan al-nafs alammarah bi al-suu'.

16 Ibid., hlm. 63.

17 Ikin Asikin, Konsep Kepribadian dalam Perspektif Psikologi Barat Kontemporer dan Islam dalam Jurnal Ta'dib, Vol. 3 No.2, Agustus 2003, hlm. 262 
Kepribadian ammarah adalah kepribadian di bawah sadar manusia. Orang yang didominasi oleh kperibadian ini, sesungguhnya ia tidak lagi memiliki identitas manusia, sebab sifat-sifat humanitasnya telah hilang. Kepribadian model ini rela menurunkan derajat asli manusia. Manusia yang berkepribadian model ini tidak saja dapat merusak dirinya sendiri, tetapi juga merusak diri orang lain. Keberadaannya ditentukan oleh dua daya, yaitu (1) daya syahwat yang selalu menginginkan birahi, kesukaan diri, ingin tahu dan campur tangan urusan orang lain. (2) daya ghadhab yang selalu menginginkan ketamakan, serakah, mencekal, berkelahi, ingin menguasai yang lain, keras kepala, sombong, angkuh dan semisalnya. Jadi orientasi kepribadian ammarah adalah mengikuti sifat-sifat binatang.

\section{Kepribadian Lawwamah (al-nafs al-lawwamah)}

Term Lawwamah hanya satu kali disebut dalam al-Quran, yaitu pada surat al-Qiyamah: 1-2, "Sungguh Aku bersumpah dengan hari kiamat dan Aku bersumpah dengan jiwa yang sangat menyesali dirinya."

Lawwamah adalah kata bentukan dari laama - yaluumu yang artinya adalah mencela. Secara bahasa, term lawwamah mengandung arti amat mencela. Dengan demikian, nafs lawwamah secara bahasa berarti nafs yang banyak mencela. ${ }^{18}$ Nafs lawwamah ini termasuk nafs tingkat tinggi karena yang dicela oleh nafs ini adalah dirinya sendiri.

Jadi, ciri nafs lawwamah adalah selalu mengeluh, kecewa dan menyalahkan dirinya. Dalam QS al-Zumar: 56 dan QS al-Maarij: 1921, disebutkan bahwa nafs menyesali dirinya atau hilangnya peluang untuk berbuat amal baik. Menurut al-Razi dalam Tafsir al-Kabir prototype nafs lawwamah dapat dicontohkan pada penyesalan Nabi Adam as ketika harus meninggalkan surga sebagai akibat kesalahannya melanggar larangan Tuhan. Nafs lawwamah termasuk nafs yang mulia,

18 Ibid., hlm. 263 
karena hanya nafs ini mendorong seseorang untuk menyesali perbuatan buruknya dan berintrospeksi atas dirinya.

Kepribadian lawwamah adalah kepribadian yang telah memperoleh cahaya kalbu, lalu ia bangkit untuk memperbaiki kebimbangan antara dua hal. Dalam upaya itu terkadang tumbuh perbuatan buruk yang disebabkan oleh watak gelapnya, namun kemudian ia diingatkan oleh cahaya ilahi, sehingga ia mencela perbuatannya itu dan selanjutnya ia bertaubat dan membaca doa ampunan.

Pengertian tersebut dapat dipahami bahwa kepribadian lawwamah berada di antara kepribadian ammarah dan kepribadian muthmainnah. Kepribadian semacam ini telah berusaha meningkatkan kualitas dirinya yang telah dibantu oleh cahaya kalbu, namun watak gelap (zulmaniyah)nya ikut campur dalam pembentukan kepribadian sehingga ia menjadi bimbang dan bingung, apakah ia mengikuti cahaya kalbu atau mengikuti watak gelapnya. Kebimbangan itu pada akhirnya akan bermuara pada tiga kemungkinan, yaitu, pertama, ia akan tertarik pada watak gelapnya sehingga tetap pada kualitas rendahnya. Kedua, ia akan tertarik oleh cahaya kalbu sehingga ia bertobat dan memperbaiki kualitasnya. Ketiga, ia berada dalam posisi netral, artinya, perbuatan yang diciptakan tidak bernilai buruk atau bernilai baik, tetapi berguna bagi kelestariannya sendiri.

Atas dasar itu, Ibn al-Qayyim membagi kepribadian lawwamah menjadi dua, yaitu : (1) Kepribadian lawwamah malumah, yaitu kepribadian lawwamah yang bodoh dan zalim, (2) kepribadian lawwamah ghayr malumah, yaitu kepribadian yang mencela atas perbuatannya yang buruk dan berusaha untuk memperbaikinya.

Jadi, nafs lawwamah menurut al-Qur'an adalah nafs yang amat menyesali hilangnya peluang baik, dan untuk itu ia mencela dirinya sendiri. Nafs dalam tingkatan ini merupakan keadaan batin yang bekerja mengawasi secara internal terhadap tingkah laku, satu kondisi dimana setiap orang yang berada pada tingkatan ini selalu mempertanyakan 
dirinya, mengkalkulasi amalnya serta mencela kesalahan yang terlanjur dilakukan, baik perkataan maupun perbuatan. ${ }^{19}$

\section{3) Kepribadian Muthmainnah (al-nafs al-muthmainnah)}

Al-Qur'an secara tegas menyebut al-nafs al-muthmainnah dalam surat al-Fajr: 27-30, "Wahai jiwa yang tenang, kembalilah kepada Tuhanmu dengan rasa puas lagi diridhai oleh-Nya. Masuklah berkumpul bersama-sama hamba-hamba-Ku dan masuklah ke dalam surga-Ku."

Muthmainnah berarti tenang setelah mengeluh dan gelisah. Nafs Muthmainnah dalam hal ini berarti jiwa yang tenang, karena ia mantap dan kuat, setelah mengalami proses interaksi dengan lingkungan yang membuatnya mengeluh dan gelisah. Maka muthmainnah dalam konteks al-nafs al-muthmainnah dalam al-Qur'an, adalah jiwa yang tenang yang ditandai dengan hal-hal berikut :

1. Memiliki keyakinan yang tidak tergoyahkan terhadap kebenaran (QS. al-Nahl:106).

2. Memiliki rasa aman, terbebas dari rasa takut dan sedih di dunia (QS. al-Nisa: 103).

3. Hatinya tenteram karena selalu ingat kepada Allah SWT (QS. al-Ra'd: 28).

Term Muthmainnah digunakan al-Qur'an tidak hanya dalam konotasi positif, tetapi juga dalam konotasi negative. Dalam QS. Yunus: 7 disebutkan bahwa orang yang tidak mempercayai adanya kehidupan akhirat dan berpuas diri dengan kehidupan dunia juga disebut tuma'ninah atau merasa tenang karena puas dengan kehidupan dunia.

Kepribadian muthmainnah merupakan kepribadian yang selalu merasa tenang dalam menerima keyakinan fitriah. Keyakinan fitriah adalah keyakinan yang dihujamkan pada ruh manusia (fitrah

19 Ibid., hlm. 265 
munazzalah) di alam arwah dan kemudian dilegitimasi oleh wahyu ilahi. Penerimaan ini tidak bimbang apalagi ragu-ragu seperti yang dialami kepribadian lawwamah, tetapi penuh keyakinan. Oleh karena itu, ia terbiasa menggunakan metode dzawq (cita rasa) dan 'ain alBashirah (mata batin) dalam menerima sesuatu sehingga ia merasa yakin dan tenang.

Bentuk-bentuk kepribadian muthmainnah diantaranya adalah keimanan, keyakinan, keikhlasan, tawakkal, tobat, taqqarrub, sabar, bijaksana, tawadlu, tenang dan cinta kepada Allah dan Rasul-Nya, memenuhi perintah dan menjauhi larangan, berani, jujur, dan semua bentuk lain yang bermotivasi pada teosentris yang berdaya positif. ${ }^{20}$

Menurut Imam al-Ghazali, nafs merupakan gabungan dari kedua makna (polisemi)

Pertama, yang menghimpun dua kekuatan ammarah dan syahwat dalam diri manusia. Penggunaan kata ini sudah lazim di kalangan sufi. Mereka memaknai nafsu sebagai asal yang menghimpun sifat-sifat tercela manusia.

Kedua, luthf yaitu hakikat, diri, dan esensi manusia. Namun, nafs ini disifati dengan berbagai sifat yang berbeda menurut perbedaan ihwalnya. Jika ia tunduk di bawah perintah hingga hilang kegelisahan karena menjauhi syahwat, ia dinamakan jiwa yang tenang (al-nafs almuthmainnah). Jika nafs tidak ditundukkan tetapi menjadi penolak nafsu syahwat, ia dinamakan al-nafs al-lawwamah. Akan tetapi, jika nafs meninggalkan perlawanan dan tunduk pada tuntutan syahwat dan panggilan setan maka dinamakan al-nafs al-ammarah bi al-suu' (nafsu yang menyuruh kejahatan). ${ }^{21}$

Di antara kedua derajat itu, terdapat derajat lain yang berada di tengah-tengah keduanya, dimana manusia selalu berintrspeksi diri atas

20 Abdul Mujib dan Yusuf Muzakir, Nuansa-Nuansa Psikologi Islam, hlm. 169

21 Ikin Asikin, Konsep Kepribadian dalam Perspektif Psikologi Barat Kontemporer dan Islam, hlm. 267. 
kesalahan yang diperbuatnya. Lalu ia berusaha keras dengan menahan diri dari melakukan apa yang dimurkai Allah dan menyebabkan penyesalan dalam dirinya. Akan tetapi, ia selalu tidak berhasil dalam usahanya. Terkadang ia lemah dan jatuh dalam kesalahan. Kepribadian dalam tingkatan semacam ini dinamakan sebagai nafsu lawwamah.

\section{Penutup}

Dari uraian di atas dapat ditarik persamaan dan perbedaan antara teori kepribadian menurut Sigmund Freud dan teori kepribadian menurut al-Qur'an. Persamaan itu adalah sebagai berikut:

Keduanya sama-sama menyatakan bahwa kepribadian manusia mempunyai tiga daya dengan karakteristik berbeda yang ketiganya berintegrasi dalam mewujudkan tingkah laku dan kepribadian manusia. Jika menurut Freud tiga daya itu secara berurutan adalah Id, Ego, dan Superego, maka dalam konsep al-Quran ketiganya disebut dengan Nafsu, Akal dan Kalbu. Yang penting dicatat disini adalah bahwa Ego dalam pandangan Freud dan Akal dalam pandangan alQur'an sama-sama berfungsi sebagai penengah ketika terjadi dorongan yang saling menarik antara Id dan Superego atau Nafsu dan Akal.

Sedangkan perbedaan antara konsep Freud dan al-Qur'an tentang kepribadian terletak pada sumber dari tiga daya yang ada dalam diri manusia. Dalam pandangan Freud, ketiganya bersumber dari diri manusia sendiri atau pengaruh pihak luar atau lingkungan, sama sekali tidak ada campur tangan Tuhan di dalamnya. Sedangkan dalam konsepsi al-Qur'an, satu dari tiga daya itu, yaitu Kalbu adalah cerminan nilai-nilai ketuhanan dalam diri manusia. Karena itu, kalbu disebut dengan fitrah ilahiyah yang berarti celupan tuhan.

Perbedaan lain terletak pada rumusan kepribadian yang dijelaskan al-Qur'an yaitu nafs ammarah, nafs lawwamah dan nafs muthmainnah. Ketiganya adalah hasil dari pergumulan antara kalbu, nafsu dan akal. 
Dalam pandangan Freud, rumusan ini tidak disebutkan walaupun secara implicit dapat dipahami dari pendapatnya.

Dari sini, dapat dikatakan bahwa kepribadian dalam al-Qur'an lebih bersifat teosentris, sedangkan dalam pandangan Freud lebih bersifat antroposentris yang hanya mengandalkan rasionalitas dan moralitas manusia.

\section{DAFTAR PUSTAKA}

Ikin Asikin, Konsep Kepribadian dalam Perspektif Psikologi Barat Kontemporer dan Islam, dalam Jurnal Ta'dib, Vol. 3 No.2, Agustus 2003, hlm. 253.

Pals, Daniel L., Dekonsruksi Kebenaran : Kritik Tujuh Teori Agama, terj. Inyiak Ridwan Muzir dan M. Syukri, Yogyakarta: Ircisod, 2003.

Lechte, John, Lima Puluh Filsuf Kontemporer dari Strukturalisme sampai Post Modernisme, terj. Gunawan Admiranto, Yogyakarta: Kanisius, 2001.

Freud, Sigmund, Memperkenalkan Psikoanalisa : Lima Ceramah, terj.

K. Bertens, Jakarta: Gramedia, 1982.

Kung, Hans, Sigmund Freud Vis a Vis Tuhan, terj. Edi Mulyono, Yoyakarta: Ircisod, 2003.

Neusch, Marcel dan Vincent P. Miceli, Sepuluh Filsuf Pemberontak Tuhan, terj. Damanhuri Fattah, Yogyakarta: Panta Rei Books, 2004. Rakhmat, Jalaludin, Psikologi Agama : Sebuah Pengantar, Bandung: Mizan, 2003.

Fromm, Erick, Psikoanalisa dan Agama, terj. Drs. Chairul fuad dan Drs. Prastya Utama, CV. Atisa, 1988.

Abdul Mujib dan Yusuf Muzakir, Nuansa-Nuansa Psikologi Islam, (Jakarta: Raja Grafindo Persada, 2001), hlm. 133.

Subandi, Psikologi dan Sufisme, dalam Membangun Paradigma Psikologi Islami (Ed.), Fuad Nashori, (Yogyakarta: Sipress, 1994). 